\title{
Change to Progress
}

With this issue of Balkan Medical Journal, it is time for me to hand over the responsibilities of Editor-in-Chief to Cem Uzun, MD. I worked as an associate editor between the years 2005-2009 and then as the Editor-in-Chief from 2009 to 2012. During these years, many achievements were made including the establishment of online submission system, change to quarterly publication, immediate acquisition of DOI number, and accepting English as the official language of the journal. ICMJE, WAME and COPE standards were accepted and applied for the publication process. In order to raise ethical standards, we began to use a plagiarism software. Enhanced manuscript submissions (both in quality and quantity) led to publication of larger volumes. As a result of these achievements, Balkan Medical Journal succeeded in being covered in the most important international indexes (SCI-E, Journal Citation Reports, EMBASE, Scopus, DOAJ, Chemical Abstracts, Index Copernicus, etc).

My successor Cem Uzun and I worked together as Associate Editors under the Editorship of Ahmet Ulugöl, MD who is the legendary name of the journal. Besides experience, hard-work and devotion, friendship was an important part of our editorial strength. Despite its sad aspects, such changes are inevitable and should be considered as a requirement of a relay-race. My editorial team and I tried to do our best, and now, I believe, the Balkan Medical Journal has become a distinguished international journal of the region. I am proud of the achievements, and also confident that the journal will continue its progress to new heights under the leadership of Cem Uzun.

I would like to thank the Associate Editors (Özer Arıcan, Nurettin Aydoğdu, Yahya Çelik, Mustafa Çıkrıkçıoğlu, Mustafa İnan, Cumhur Kılınçer, Nermin Şakru, Zafer Koçak, Cenk Sayın) and Editorial Secretary (Elif Ezgi Gürel) for their hard work. I also would like to thank Gökhan Çimen, Sevilay Ardıç, and İbrahim Kara of AVES Yayıncılık, the Publisher, who solved all bureaucratic issues and provided support in every occasion. Finally, I would like to invite each reader of the Balkan Medical Journal to continue supporting the Journal through their valuable contributions, submissions and feedbacks. Your contributions are essential for the Balkan Medical Journal to help it achieve its goals which basically include contributing to medical sciences and healthcare in the Balkan area through increased scientific productivity and continuous medical education.

\section{Levent Öztürk}

Editor-in-Chief

Balkan Medical Journal, Department of Physiology, Faculty of Medicine, Trakya University, Edirne, Turkey 